\title{
Medieval Daoist Concepts of the Middle Kingdom
}

\author{
$L i u Y i$ 劉屹 \\ Professor of History, Capital Normal University, China \\ lygog4@sohu.com
}

Translated by Casey Lee

\begin{abstract}
The ancient Chinese people believed that they existed at the center of the world. With the arrival of Buddhism in China came a new cosmic worldview rooted in Indian culture that destabilized the Han [huaxia 華夏] people's long-held notions of China as the Middle Kingdom [Zhongguo 中國] and had a profound influence on medieval Daoism. Under the influence of Buddhist cosmology, Daoists reformed their idea of Middle Kingdom, for a time relinquishing its signification of China as the center of the world. Daoists had to acknowledge the existence of multiple kingdoms outside China and non-Han peoples [manyi 蠻夷] who resided on the outskirts of the so-called Middle Kingdom as potential followers of Daoism. However, during the Tang dynasty, this capacious attitude ceased to be maintained or passed on. Instead, Tang Daoists returned to a notion of Middle Kingdom that reinstated the traditional divide between Han and non-Han peoples.
\end{abstract}

\section{Keywords}

cosmology - Daoism - Middle Kingdom - Zhongguo

\section{Introduction}

As is the case with many older civilizations and peoples, the ancient Chinese considered themselves the center of the world and thus named themselves Zhongguo 中國, the Middle Kingdom. To be the center of the world signifies not only the geographic location of a country but also the territorial reach of its political, economic, and cultural influence. From this stems the Chinese 
people's predetermined sense of superiority over the bordering ethnic groups and their cultures. Generally, one thinks of the Zhongguo of ancient times as a civilization, rather than a place with distinct geographic boundaries. If anything, it vaguely referred to the land under the de facto control of the ruling dynasties of the central plains and, thus, shifted along with the territory of each dynasty. What lay outside Zhongguo was thought to be the untamed borderlands of culturally inferior people.

With the arrival of Buddhism in China came a new cosmic worldview rooted in Indian culture. Buddhist scriptures generally consider the Magadha kingdom at the Ganges River basin the center of the world, which clashed with Chinese notions of itself as the Middle Kingdom. For those familiar with mainstream Chinese culture and traditions, the impact of this clash may not seem apparent. People generally consider the Chinese view of itself as the center of the world to have remained intact until Matteo Ricci's late sixteenthcentury mission to China and, further, that it was not until the Opium War in the 1840 s that China was forced to abandon its sense of cultural superiority as a heavenly mandated empire. In other aspects, however, the impact of this clash was clearly felt. This is certainly the case for devout Chinese Buddhists across Chinese history. This is also the case with medieval Daoism. The common view of Daoism as a strongly homegrown Chinese religion is supported by such Daoist texts as the "Treatise on the Chinese and the Non-Chinese" [Yixia lun 夷夏論] and the "Conversion of Barbarians" [Huahu shuo 化胡說], which both emphasize Chinese cultural and ethnic superiority over bordering populations and reflect an attitude of intolerance toward non-Han worldviews. However, the reality is more complicated.

Related research on the topic tends to begin with a survey of Daoist discussions of "barbarians" and "heretics." For instance, Kristofer Schipper, in his study of medieval Daoist texts, traces changing Daoist notions of "barbarians." As he points out, Daoism was first aligned with Buddhism in opposing certain traditional Chinese religious practices, such as sacrificial rites involving the taking of life. Thus, at the time, Daoist attitudes toward non-Han cultures were friendly. By the Tang dynasty [618-907], however, the relationship between Buddhism and Daoism had shifted to the point that the surrounding non-Han tribes became a target of Daoist hostility. ${ }^{1}$ Yamada Takashi has also explored Daoist ideas of "barbarians" and "heretics," noting the Daoist belief that those born in the Middle Kingdom accrued good karma from past lives and, thus, have exclusive access to Daoist teachings and the ability to achieve

1 Kristofer Schipper, "Purity and Strangers: Shifting Boundaries in Medieval Taoism," T'oung Pao 80 (1994). 
Daoist self-cultivation. In contrast, those born in foreign kingdoms carry the retribution of sins committed in past lives and are no more than pitiable vermin who may "have human form, but no human emotions." Such "heretics" all live in faraway and desolate lands. ${ }^{2}$ Such Daoist ideas are clearly premised on traditional notions of Chinese cultural and geographic superiority.

This article explores the following questions: What Daoist concepts of the Middle Kingdom existed during medieval China? Are they consistent with the Middle Kingdom as conceived in traditional Chinese culture? Did it undergo a change during the medieval era? Finally, what is the value of interrogating the transformation of "Middle Kingdom" as a medieval Chinese concept?

\section{The Concept of "Middle Kingdom" in Early Six Dynasties Daoist Texts}

At the start of the Eastern Jin dynasty [317-420], Ge Hong 葛洪 [283-343] lists in the "Jindan" 金丹 chapter of the Inner Chapters of the Baopuzi [Baopuzi neipian 抱樸子內篇] the names of many well-known Chinese mountains, including Mount Hua 華山, Mount Huo 霍山, Mount Heng 恆山, Mount Song 嵩 山, Mount Taibai 太白山, Mount Zhongnan 終南山, Mount Wangwu 王屋山, Mount Qian 潛山, Mount Emei 娥眉山, Mount Luofu 羅浮山, Mount Tiantai 天臺山, and Mount Kuocang 括蒼山. As these were all sacred mountains where deities reside, Daoists visiting these mountains to gather medicine and pursue Daoist self-cultivation could receive the help of the mountain gods. Ge was writing after the Yongjia Uprising [311], when the northern central plains were under the control of the Five Northern Tribes. Thus, he writes: "At present, it is no longer possible to reach the sacred mountain ranges at the heart of China. There are still mountain ranges where it is possible to retreat in the Jiangnan 江南 region."3 The sacred mountains that Ge lists cover present-day Shaanxi 陝西, Shanxi 山西, Henan 河南, Anhui 安徽, Sichuan 四川, and Zhejiang 浙江 Provinces, with the major range being the sacred mountains of Kuaiji 會稽 in the Jiangdong 江東 region. Therefore, it is apparent that, whereas Ge considers Jiangdong — a region formerly ruled by the Eastern Jin—part of the Middle

2 Yamada Takashi 山田俊, “Rikuchō kara Tō no dōkyō bunken ni mirareru iteki to gedō 六朝 から唐の道教文獻に見られる夷狄と外道 [Barbarians and Heretics as Seen from Daoist Texts from the Six Dynasties to the Tang]," in Sankyō kōshō ronsō 三教交涉論叢 [Interactions Between the Three Teachings], ed. Mugitani Kunio 麥谷邦夫 (Kyoto: Kyoto daigaku jinbun kagaku kenkyūjo, 2005).

3 Wang Ming 王明, Baopuzi neipian jiaoshi 抱樸子內篇校釋 [Collation and Explication on the Inner Chapters of the Baopuzi] (Beijing: Zhonghua shuju, 1985), 85 . 
Kingdom, after the Jin ruling house relocated to the south, a division formed between Jiangdong, located at the lower reaches of the Yangtze River, and the Middle Kingdom concentrated in north China.

A similar concept of Middle Kingdom is seen in chapter 14, "Investigating the Spiritual Pivot" [Ji shen shu 稽神樞], of the Declarations of the Perfected [Zhen'gao 真誥], which reads: "Ping Zhongjie 平仲節 was a man of Hezhong 河中. When the 'Great Barbarian 大胡' brought chaos to the central plains, Ping crossed the Yangtze River and arrived at Mount Kuocang." ${ }^{4}$ Here, "Great Barbarian" refers to Liu Yuan 劉淵 [250-310] and the "chaos" he brought to the central plains refers to the Yongjia Uprising. The first section in chapter 15, "Revealing the Profoundly Faint" [Chan you wei 闡幽微], in the Zhen'gao describes how Sun Ce 孫策 [175-200], "after inheriting his father's position led his followers to seize control of the Jiangdong region and then hoped to unite the central plains (zhongguo)."5 Here, Jiangdong and Zhongguo are treated as separate entities. In the same section, the text continues:

Mount Luofeng 羅酆 is in the position of gui 癸. The gui location here probably does not refer to one of the twelve heavenly stems, but, instead, to the direction one faces with the central plains at the center. In this case, this corresponds to somewhere north of Youzhou 幽洲 and Liaodong 遼東, in the northern seas who knows how many tens of thousands of li 里 from the shore. ${ }^{6}$

Here, again, one can see how the Middle Kingdom still refers to the northern central plains. The Zhen'gao was compiled by Tao Hongjing 陶弘景 [456-536] in the Liang dynasty [502-557] from the Highest Purity [Shangqing 上清] Revelations of Yang Xi 楊羲 [330-c. 386] and the Xu 許 family, who lived during the first half of the Eastern Jin dynasty. Tao is responsible for the commentary that appears in the text. The way in which the text uses zhongguo seems to reflect how the transmitters of Highest Purity traditions understood the geographical reality of the Middle Kingdom from the Eastern Jin to Liang dynasties.

The first ten chapters of the Scripture of the Divine Incantations of the Cavernous Abyss [Dongyuan shenzhou jing 洞淵神咒經] were completed during the period from the Jin [265-420] to the Liu Song [420-479]. The first volume in the Dunhuang 敦煌 manuscript version reads:

4 Daozang 道藏 [Daoist Canon] (Beijing: Wenwu chubanshe, 1988), 6:574c.

5 Ibid., 6:583b.

6 Ibid., 6:579a. 
During the jiawu 甲午 year, the Liu clan returned to the central plains and established their rule in Chang'an. The people of the Qinzhou 秦州 District were overjoyed. The surrounding non-Han tribes were subjugated and went back to live in the wilderness, not to return to their residences in the central plains. Daoism began to prosper. ${ }^{7}$

This passage recounts the historical event in which Liu Yu 劉裕 [363-422; r. 420-422] of the Eastern Jin once overtook Guanzhong 關中 for some time. Chapter 6 in the same text reads: “The Dao says, 'from now until the jiaxu 甲戌 and renwu 王午 years, disciples of Buddhism in the Middle Kingdom will gradually weaken and die out. With each day, Daoism will flourish in the Jiangnan and Sichuan areas."'8 The emphasis here is that, whereas Buddhist monks in the Middle Kingdom will languish and perish, Daoism will continue to flourish in the Shu-Han territory of the Jiangnan. This passage treats the areas under the rule of the Eastern Jin and Southern Dynasties [420-589] as geographically separate from the Middle Kingdom. It seems, then, from the perspective of a person living during the period from the Jin to the Liu Song, zhongguo refers exclusively to the northern central plains and Guanzhong areas. At the same time, the Jiangdong region, while formerly considered a part of the Middle Kingdom, had succumbed to a momentary period of decline due to foreign invasion. During this period of decline, cultural legitimacy and advances in Daoism were concentrated in Jiangdong instead.

Although a geographical sense of zhongguo is contingent on such shifts in geopolitics, its sense as the center of civilization and enlightenment remains unchanged. The Yixia lun, by Gu Huan 顧歡 [fl. 420-479] in the Southern Qi dynasty [479-502], establishes a dichotomy between the "Han people of the central plains" [Zhongxia 中夏] and "the Rong people in the west" [Xirong 西戎]. It considers Daoism the only religious teaching pure and righteous enough to fit the culture of the Han people and their lands whereas Buddhism and its teachings are suited to the lands of the Rong people. Whether in terms of nomenclature or geographic boundaries, Zhongxia is indistinguishable from zhongguo in the works of Gu Huan as well as Ge Hong and Tao Hongjing because both refer to a place centered on Han civilization.

7 See also Daozang, 6:3b, for comparison. Some of the language of the two texts vary. For instance, the Daozang version uses renshi 人氏 where the Dunhuang manuscript says Liu shi 劉氏.

8 See also Daozang, 6:20a, for comparison. Some of the language in the two texts vary. For instance, the Daozang text does not use the phrase Zhongguo shamen 中國沙門 [Chinese monks]. 
During the Six Dynasties period [220-589], Daoism tended to abstract and conceptualize zhongguo to de-emphasize the significance of its geographical sense in favor of its valence of cultural superiority. This can be seen in chapter 6 , “Instructions for Shaping Destiny” [Zhen ming shou 甄命授] in the Zhen'gao:

The Lord of the Western Citadel told his wife, "To leave the three evil paths and to also become human is difficult. Should one become human, to also be born as a man, and not a woman, is difficult. Should one be born as a man, to also be one without disability, is difficult. Should one be born without disability, to also be born in the Middle Kingdom is difficult. Should one be born in the Middle Kingdom, to also encounter a worthy emperor and parents is difficult. Should one encounter a worthy emperor and be born into a practicing Daoist family, to also possess a kind, humane, and good heart is difficult. Should one possess a good heart, to then also believe in Daoism and immortality is difficult. Should one believe in Daoism and immortality, to then also encounter "the Great Peace Kalpa in renchen 王辰 year" is difficult. How can one not strive?"9

According to this passage, only those who live in the Middle Kingdom and are of sound bodily and sensory faculties have the capacity to cultivate the Dao. Further, those residing outside are all "only human in form, not in feeling" and, therefore, cannot directly receive the benefits of Daoist teachings. Whether one is born in the Middle Kingdom became a condition for participating in Daoist practice.

The early Lingbao 靈寶 scriptures in the Jin to Liu Song period also promote this line of thinking. Chapter 46 of the Secret Essentials of the Most High [Wushang biyao 無上秘要] cites the "Major Precepts of the Upper Chapters on Wisdom and the Ten Virtues" [Zhihui shishan dongzhu shangpin dajie 智慧 十善動助上品大戒], in the Scripture of the Upper Chapters on Wisdom in the Dongxuan Tradition [Dongxuan zhihui shangpin jing 洞玄智慧上品經], thus:

9 Daozang, 6:523b-c. For more on this passage, see also the juan shang 卷上 of the Shangqing zhongzhen jiaojie dexing jing 上清眾真教戒德行經. There is some variation in the wording. A point worth noting is that some have taken this passage as a case of the Zhen'gao copying the Buddhist Sishi'er zhang jing 四十二章經 [Sutra in Forty-Two Parts]. The original Buddhist scripture says, "though the six conditions be met, still it is difficult to be born in the Middle Kingdom 六情已具, 生中國難." Here, “middle kingdom” originally refers to the core district in India for the transmission of Buddhism. However, among Daoists, some borrowed this saying and took zhongguo 中國 [Middle Kingdom] to mean zhongxia 中夏 [Chinese]. 
Article 5: aid Daoist masters in acquiring ecclesiastical robes and one may, in a different life, reside in the Middle Kingdom and, thus, live a carefree life without being cast to wander in the borderlands of the ManYi. One's children will be of honest and handsome comport, wearing the hat of officials and jade ornaments. ${ }^{10}$

Chapter 74 in the same texts cites the Scripture on Affirmations in the Dongxuan Tradition [Dongxuan dingzhi jing 洞玄定志經], saying: "Should one encounter non-Han people such as the Man or Yi people, you should wish that all living creatures, when reincarnated, be born into the Middle Kingdom and not a border area or beyond."11

In these passages from Daoist texts in the Eastern Jin and Southern Dynasties, zhongguo is the center of the world's most advanced civilization, with Daoism as the only doctrine suited to its land and people. In contrast, the four or five non-Han tribes, because of retribution for the sins of past lives, are born in the borderlands and thus unable to access the Dao. Their only chance to cultivate immortality is to be born in the Middle Kingdom in a subsequent life. Thus, in the south at this time, the Middle Kingdom has two meanings: first, there was the material Zhongguo, which has relatively a clear and established geographic location; second was the conceptual zhongguo defined as culturally superior to borderland ethnicities. According to the Daoist teachings at the time, those who are culturally superior people of the Middle Kingdom do not necessarily have to reside within the geographic boundaries of the Middle Kingdom because those who are culturally Chinese are able to cycle through many lives without limits. Additionally, non-Chinese people can devote themselves to the Dao and, through accumulating good deeds, be reborn as Chinese in a subsequent life. Similarly, a person who is geographically Chinese can, because of the accumulation of sins, be reborn as a non-Chinese person. This ideology reflects the influence of the Buddhist concepts of reincarnation and karmic retribution.

The influence of Buddhist thought on the Daoist sense of the Middle Kingdom goes even deeper. Originally, China had only a uniplanar concept of five directions, which included the four cardinal directions plus a center. With the introduction of the Buddhist ten directions concept, the Chinese added to their five directions a zenith [shang 上] and nadir [xia 下] to achieve three-dimensional space. As the nadir overlaps with the center, which was

\footnotetext{
10 Daozang, 25:164b.

11 Ibid., 25:226a.
} 
already one of the original five directions, this created a six-directional space, a compromise between the Chinese uniplanar five-directional space and the Buddhist multiplanar ten-directional space. The Highest Purity Esoteric Text of the Green Land on Goods Deposited in Foreign Lands [Shangqing waiguo fangpin qingtong neiwen 上清外國放品青童內文], a classic Shangqing text, contains descriptions of six kingdoms located along the six directions of the world. It lists the country of Harati 啊羅提 to the north, the country of İşāta 伊沙陀 to the south, the country of Niviralünā 尼維羅綠那 to the west, the country of Suntarā 旬他羅 in the north, the yuanjing qingdun ziran 元精青沌 自然 country at the zenith, and the taihe baozhen wuliang 太和寶真無量 country at the center. This text also describes a Middle Kingdom as follows:

The Middle Kingdom is located at the southern tip of the Lake of the Great Wind, 520 billion li from dry land. It maintains the earth's core, keeping it from falling. The land of the Middle Kingdom is as exquisite as gold. Its music is engraved in the country at the center. The central mountain Mount Kunlun, another name for the many levels of heaven, is at its heart. Beyond Mount Kunlun is the Palace of the Hanging Garden and Seven Treasures, the abode of immortals. Beyond that, one is level with the sky. The periphery of the Middle Kingdom runs 120 billion li. Its people are nine feet [chi 尺] tall. They all engage in "pulling and guiding" exercises and live to be 1,200 years old. The Middle Kingdom possesses the Inscription of the Six Tones 六音之銘, placed there by the Jade Emperor on High. Its people can sing out its sounds to move the masses of lower society as well as the old, allowing them to understand that the teachings of the Middle Kingdom hold the promise of immortality. Thus, its people practice the doctrines of Higher Purity, holding rituals, internalizing the songs, and, in doing so, live for 1,200 years without fear of sudden or early death. ${ }^{12}$

The Middle Kingdom discussed here is neither the geographic sense of zhongguo nor a zhongguo that is culturally superior to its surrounding foreign countries; it is a religious-mythical zhongguo. The six kingdoms of the six directions have equal standing; the Middle Kingdom is not treated as the center of Daoist

12 Daozang, 34:12c-13a. For more on the Daoist appropriation of the Buddhist "ten directions" in the Shangqing waiguo fangpin qingtong neiwen 上清外國放品青童內文 [The Highest Purity Esoteric Text of the Green Lad on Goods Deposited in Foreign Lands], see Erik Zürcher, "Buddhist Influence on Early Taoism: A Survey of Scriptural Evidence," T'oung Pao 66 (1980): 110. 
doctrines. The existence of this mythical Middle Kingdom in this text reflects the steady influence of Buddhist cosmology on Daoism. During the first half of the Six Dynasties period, this influence was not yet strong enough to alter the Daoist concept of the Middle Kingdom; by the end of the Northern and Southern Dynasties [420-581], however, it had become strong enough to affect a Daoist reconceptualization of zhongguo. Southern Dynasties to the Tang Dynasty

In 570, Zhen Luan 甄鸞 [535-566] cited a Daoist manuscript known as Scripture on Relieving Suffering [Jiku jing 濟苦經] in his Laughing at the Dao [Xiaodao lun 笑道論] to discuss a new cosmic worldview that was heavily influenced by Buddhist teachings. Zhen Luan drew only from excerpts of the Jiku jing. Later, it circulated as a chapter in the Supreme Scripture of the Marvelous Dharma and Original Forms [Taishang miaofa benxiang jing 太上妙法本相經] as well as the Tang dynasty text, Dongxuan lingbao Scripture of Original Forms and Cycles of Kalpas [Dongxuan lingbao benxiang yundu jieqi jing 洞玄靈寶本 相運度劫期經]. I cite and discuss a passage from the Jieqijing:

Between the sky and earth is 150 million li. Mount Kunlun 昆侖 is the center of the earth. Between heaven and earth there are eighty-one halls, which are also called the eighty-one skies. The four directions that Kunlun faces constitute four worlds. Mount Kunlun is the source of the four great seas, which flow from the foot of Mount Kunlun out in four directions before returning to the abyss. Mount Kunlun, at 15,00o li high, is the tallest mountain on earth. Three quintillion li south of Mount Kunlun is another Mount Kunlun. North, south, east, west - the four sides of this Mount Kunlun, like the last, are also of an incalculable vastness. Between the two Mount Kunluns, every full thousand is called "one." If you count a thousand of these ones, you get a number called "two." If you then count a thousand of these twos, you get a number called "three." When you have counted a thousand of these threes, you get a number called "small number one [xiao shuyi 小數一]." When you have counted a thousand of these "small number ones," you get a number called "one." A thousand of these "ones" makes "two"; a thousand of these "twos" makes "three"; after repeating this process three times, you get a "middle thousand [zhongqian 中千]." After using the same counting process on this "middle thousand" three times, you get a "great thousand [daqian 大千]." Thus, 
you have a great chiliocosm [sanqian shijie 三千世界] managed by the immortals in ten directions. ${ }^{13}$

If we replace "Mount Kunlun" here with "Mount Meru 須彌山," this passage would be nearly indistinguishable from Buddhist cosmological discussions of the chiliocosm or "one billion worlds" [sanqian daqian shijie 三千大千世界]. Borrowing the concept of a great chiliocosm clashes greatly with the Daoist cosmology and creation stories. For one thing, zhongguo no longer designates the "center of the world." Instead, Mount Kunlun is the center of every world while there is no center within or among the "one billion worlds." Such a worldview is present neither in the old Lingbao scriptures of the south nor in the Shangqing texts of the Jin to Liu Song period. This is not because southern Daoists were unaware of Buddhist cosmology when they created Daoist scriptures; rather, they openly rejected it to avoid having it threaten their worldview. However, the Jiku jing chapters at the end of the Northern Dynasties [386-581] nearly adapted the language of such Buddhist cosmology word for word. It was then transmitted via the Benxiang jing and Jieqi jing through to the Tang dynasty.

The Benxiang jing was one of the first Daoist scriptures created in the final years of the Northern Dynasties. When Zhen Luan was alive, it had about eight to ten chapters, including "Perfected One of the Eastern Pole Inquires into the Categories of Things" [Dongji zhenren wen shipin 東極真人問事品]. ${ }^{14}$ Chapter 9, which has been passed down to us through its Dunhuang manuscript version, subscribes to the same cosmology as the Jiku jing (Jieqijing version). It offers a new parameter for understanding both zhongguo and Han territory [handi 漢地]. The Benxiang jing follows the Jinglao 靜老 Celestial Lord's travels to the four regions in the four directions. When he arrives in a country, he draws on Daoist doctrines to convert the king and officials. The extant chapters show that the countries that he visited include Xi'nayu 西那玉, Gaoyang 高陽, Fuli 浮黎 and Chunhe 純和 to the east, Chiming 赤明 to the south, Datang 大堂 to the west, Wuliangyu 無量玉 to the north, and Qinglingshilao 青靈始老. These kingdoms, which are in various directions and areas, do not reflect the Six Dynasties' notion of a Middle Kingdom surrounded on four sides by "barbarian" land. Rather, it resembles the system of a

13 Daozang, 5:852b-c.

14 For more on the Benxiang jing, see forthcoming works by the author. The Benxiang jing was completed before 570 by a Daoist in the Northern Dynasties. By the early Tang, it had increased to twenty-three volumes and was likely a major work of the period. 
great chiliocosm. In fact, these kingdoms seem to exist on an entirely different plane than China.

A passage in chapter 9 in the Benxiang jing reads:

The Celestial Lord said: You have said that there are countless countries in the ten directions, an incalculable amount. There is a country on the east-facing side of Mount Kunlun called "the great land of Fuli." Within Fuli are 99,999 smaller countries. (Below you list examples, such as the nine countries of Piyi 罵夷, Jiji 雞集, Hucheng 虎成, Niuhao 牛號, Zang'gu 牂羖, Muma 木馬, Kang'gou 康狗, and Shibi 豕庳. Of these, the people of Kang'gou and Shibi "have the same hands and feet as the people of China.") The "nine barbarian countries" [jiuyi zhi guo 九夷 之國] on the east-facing side of Mount Kunlun refer to these nine. The remaining 99,999 countries are all "Han countries" [hanguo 漢國]. The Han people are mostly descendants of heaven; they are not related to the nine barbarian peoples. Only the truly pious followers of the way can be born in the "land of the Han" [hanzhong 漢中]. These eastern countries are all worthy of receiving Daoist doctrines. However, the "nine barbarian countries" are not. ${ }^{15}$

Most of the people from these non-Han countries have physical characteristics as well as manners and rituals that are far different from those of Chinese people. They cannot directly receive Daoist doctrines either. Aside from these nine countries, all the others are "Han territory" where celestial beings are reborn as human beings so that they can devote themselves to the Dao. In this passage, the nuances of zhongguo, handi, and hanzhong are similar. ${ }^{16}$ Whether one is able to practice the Dao distinguishes the "Middle Kingdom" and "Han territory" from the "nine barbarian countries." At the same time, as countries within a great chiliocosm, not one of these categories of designation is singular. Thus, from Gu Huan's binary division between zhongxia and xirong to the Benxiang jing's distinction between handi and jiuyi, there is a proliferating worldview that transcends set ideas about geopolitical territory and space.

15 Tianjin shi yishu bowuguan 天津市藝術博物館, Tianjin shi yishu bowuguancang Dunhuang wenxian 天津市藝術博物館藏敦煌文獻 [Tianjin Art Museum Collection of Dunhuang Documents] (Shanghai: Shanghai guji chubanshe, 1997), 6:158-6o.

16 Here, hanzhong 漢中 recalls a line from Gu Huan's treatise: “The Inner Chapters of the Xuanmiao 玄妙內篇 [Xuanmiao neipian]" is a true canonical work of hanzhong, not an inelegant text." Wang Ka once shared in a personal communication with me that the meaning of hanzhong should be China, but many believe it is synonymous with the territory occupied by Zhang Lu 張魯. I believe that Wang Ka is correct. 
Even so, as a Northern Dynasties text, the Benxiang jing holds on to a concept of "barbarians" that is rather different from what one might find in the southern Daoist scriptures of the early Six Dynasties period. Daoist scriptures from the south distinguish between Han and non-Han peoples by adhering to the central territory of the ruling houses of the Han, Wei, and Jin [202 BCE-420] as the demarcation for zhongguo. In contrast, the Benxiang jing takes Mount Kunlun as the center of the universe to determine the boundaries between the Han and non-Han. Thus, while early Six Dynasties Daoist scriptures espouse the idea that only the Middle Kingdom is suited for Daoist religious conversion, the Benxiang jing holds that, within the vastness of universes and worlds, only the "nine barbarian kingdoms" are excluded from Daoist indoctrination. Put in this light, the debates regarding Han and non-Han peoples that occurred tirelessly from the end of the Han to around the Southern Qi dynasty [479-502] (exemplified by the "Huahu shuo" and "Yixia lun") seem rather pointless.

After all, the geographic zhongguo refers not only to the central territories of the Han, Wei, and Jin ruling houses as well as the Jiangdong region but also "Han territories" where non-Han people reside. If one considers the northern origin of the Benxiang jing, it is easy to see that northern Daoists saw areas to the north and west traditionally considered "barbarian territory" as well as the territories overtaken by the non-Han Northern dynasties rulers as Han territory whose people would naturally be able to receive Daoist teachings, regardless of ethnicity. This understanding adds a new dimension that explains how the Daoists, historically so trenchantly nativist, were able to handle the religiouspolitical relationship with northern non-Han rulers despite the prevalence of ethnically divisive ideologies. It also answers the question of how there are so many non-Han converts to both Buddhism and Daoism apparent in the material evidence from the time. It is likely that maintaining an open-mindedness regarding the division between Han and non-Han peoples is one of the reasons that the northern Daoists could work with non-Han rulers to attract a large non-Han following.

From the Daoist traditions of the latter Southern dynasties to the tablet inscriptions in Tang dynasty Daoist temples, discussions on the number of Daoist scriptures tend to follow the same script. Chapter 2 in the Pivotal Meaning of Daoism [Daojiao yishu 道教意樞], by Meng Anpai 孟安排, cites the Text of the Doctrine of Right Unity: Scriptures and Diagrams on Rules and Precepts [Zhengyi fawen jingtu kejie pin 正一法文經圖科戒品], saying:

From the beginning of creation to the end of the kalpa, China has 123,000 scrolls of important Daoist classics under one heaven. The remainder are spread in the four directions among the barbarian tribes, 
which each have 84,00o. The discourse and language across these texts are consistent; they differ only in how finely they lay out their arguments and how they divide their chapters. ${ }^{17}$

The Origins of the Marvelous Gates [Miaomen youqi 妙門由起] completed in 713 cites the Supreme Protocols of the Great Perfected [Taishang taizhen ke 太上 太真科], saying:

If one were to select only the most essential texts out of all the Daoist classics under one heaven, the amount would still be innumerable. From the beginning of creation to the end of the kalpa, China has 123,000 scrolls, while the barbarian tribes each have 84,000 of the remainder. Any that remain thereafter have not been definitively accounted for. ${ }^{18}$

In Renshou County, Sichuan, the Record of the Nanzhu Temple [Nanzhu guan$j i$ 南笂觀記] stele inscription from the eighth year of the Tianbao 天寶 reign [742-756] reads:

The number of all the "precious scriptures of the three caverns" under one heaven total 367,000 scrolls: 244,000 of them are scattered across the borderlands in the four directions, while 123,000 of them are in China. The Shangqing scriptures total 100 scrolls; the Lingbao scriptures, 40 scrolls; the Sanhuang 三皇 scriptures, 14 scrolls; the Taiqing 太清 scriptures, 36 scrolls; the Taiping 太平 scriptures, 170 scrolls; the Taixuan 太玄 scriptures, 270 scrolls; the Zhengyi 正一 scriptures, 200 scrolls; in addition to these, there are 70 scrolls of amulets and charts. Classics such as the Shengxuan 升玄, Benji 本際, Shenzhou 神咒, Shengji 聖紀, Huahu 化胡, Zhen'gao 真誥, Nanhua 南華, Dengzhen 登真, and Biyao 秘要 comprise about 1,00o scrolls. Altogether, they total 2,100 scrolls that currently exist in the world, such as works outside the Daoist canon, including Confucian

\footnotetext{
17 Daozang, 24:815b.

18 Ibid., 6:734a. For recent scholarship on the Taizhenke, see Ōfuchi Ninji 大渊忍爾, Dōkyō to sono kyōten 道教とその經典 [Daoism and Its Canon] (Tokyo: Sōbunsha, 1997), 409505. According to Ōfuchi, the Taizhenke first appeared in book form before 440 and was expanded and revised in the sixth century. The Taizhenke originates in the study of scriptures and Daoism in the south during the Jin to Liu Song period. Its use in the Tangdynasty Miaomen youqi likely includes ideas from the end of the Northern and Southern Dynasties period.
} 
classics. Additionally, 128,070 scrolls collected within the three caverns of the heavenly realm have not circulated in the world. ${ }^{19}$

A study of the dynastic records of Daoist scriptures from the Eastern Jin to the Tang dynasty reveals that in fact "little more than one thousand scrolls" truly represent Daoist scriptures. Thus, these accounts of the number of Daoist texts are undoubtedly exaggerated.

It is notable, however, that without exception they use the phrase "under one heaven [yitian zhixia 一天之下]," rather than "under heaven [tianxia 天下]," implying that there is more than one world. The Nanzhu guanji inscription mentions that, of the 367,000 existing scrolls, only 123,000 are in zhongguo, while 244,00o belong to the surrounding "barbarians." The attitude expressed here differs greatly from the early Six Dynasties view that the surrounding non-Han peoples "have human form, but not human emotions." This is likely the result of the Daoist reconceptualization of the notion of zhongguo under the influence of Buddhist cosmology. In these texts, it seems that Daoists have abandoned the idea of China as the center of the world. Instead, there is an acknowledgment of more than one world and, thus, more than one middle kingdom; moreover, there is a recognition that the surrounding non-Han peoples can also devote themselves to Daoist doctrines. Compared to the early years of the Southern Dynasties, where the Han-barbarian divide was strongly upheld within Daoism, this is certainly a revolutionary change.

All the same, this revolutionary change was not maintained or passed on during the Tang dynasty. Some in the early Tang (i.e., during the reign of $\mathrm{Xu}-$ anzong [r. 712-756]), a Daoist text appeared called the "Supreme Great Dao Scripture of Jade Purity" [Taishang dadao yuqing jing 太上大道玉清經] that held clearly anti-Buddhist attitudes. ${ }^{20}$ In discussions of foreign people receiving Daoist doctrines that appear in chapter 2 in this work, the tone of this text reverts to that of the early Six Dynasties.

19 For more on this well-studied stele, see Liu Yi, "Research into the Catalogue of the Daozang of the Early Tang Dynasty: Based on Nanzhu guan ji and the Daoist Scriptures of Dunhuang," in Scriptures, Schools and Forms of Practice in Daoism: A Berlin Symposium, ed. Poul Andersen and Florian C. Reiter (Wiesbaden: Harrassowitz, 2005), 191-92.

20 Schipper places the completion of this text at around $75^{\circ}$, the height of the Tang dynasty when it was at once progressive and vast, but also inwardly harbored a narrow-minded culture of Han nativism. See Schipper, "Purity and Strangers," 63. In his contributions to The Taoist Canon: A Historical Companion to the Daozang, John Lagerwey writes that this text was completed during a time of intense debate between Daoists and Buddhists. See Kristofer Schipper and Franciscus Verellen, ed., The Taoist Canon: A Historical Companion to the Daozang (Chicago: University of Chicago Press, 2004), 1:525-27. 
The Celestial Lord said, "the land of those countries is humid and toxic. The people of those [border] countries are the same. How came this to be? Thus, the land is called 'the golden direction' for all manner of creatures are born in such a remote place. The people there know not of the true and right teachings, only the "three vehicles" and apadana of Buddhism. They know nothing of the Daoist Secret Precious Canon, the Mysterious Seal Script of the Heavenly Realm, or the Patterns of the Dragon and Phoenix. They are not aware that Daoist doctrines are the doctrines of the immortals ascended to the heavenly realm." Hearing the Celestial Lord speak, the listeners feared that their bodies and fortunes were not up to Daoist standards and, thus, all began to weep piteously, kowtowing until they bled. They once again asked the Celestial Lord, "The people living there spent their days in such a dirty and smelly place. How dare they dream to achieve immortality within their lifetimes and tie their fates to the Dao? They can only hope, in their next lives, to be reborn in the Middle Kingdom where the Dao exists. We only hope, oh great and merciful Celestial Lord, that you grant us the methods to fast, cultivate ourselves, and perform the rituals." ${ }^{21}$

The "Preface to Laozi's Western Ascension and Conversion of Barbarians" [Laozi xisheng huahu jing xushuo 老子西升化胡經序說] is a work of similar ilk that is also part of the Dunhuang manuscripts completed during the Xuanzhong period. The opening describes a scene where Laozi converts eighty-one barbarian kings in Khotan.

You people have vicious hearts, enjoy the taking of life, only consume blood and meat, and bring harm to all living creatures. I hereby preach to you the Yaksha Scripture and command that you stop eating meat, only eat wheat and flour, and stop killing and harming. Those who cannot are no better than dead flesh. The barbarians were ferocious, devoid of regard for even their own kin. They feel only greed and lust, no gratitude or loyalty. Their hair is curly and difficult to maintain and clean. Their bodies reek of animal scents and filth. If they were to practice cultivation in this state, it would only vex others. Therefore, let them cut off their hair and beards, leaving only their clothing of their customary furs and sackcloth. Let them hold to the commandments and slowly regain hearts of kindness. On the fifteenth of each month, they should repent.

21 Daozang, 33:291b. 
Here, the border populations once again become people who are ignorant of Chinese customs and in need of a great Daoist master to dictate them. At the very moment when the Tang was at the height of its power and its people at their most confident and most progressive was also when an old sense of cultural superiority was revived. ${ }^{22}$ Daoist understandings of the "Middle Kingdom" likewise reverted from being part of a cosmic worldview to being one based on a racial-ethnic binary. At first, this reversion might have been a case of the magnificence of the flourishing Tang naturally feeding a sense of pride, confidence, and self-indulgence. Once it met with the chaos of the An Lushan Rebellion, however, the recoil from the previous period of openness resulted in a growing tendency toward isolation..$^{23}$

The preceding discussion draws on a modest body of texts to offer a sketch of how medieval Daoist ideas of zhongguo transformed over the period from the Six Dynasties to the Tang dynasty. Beginning with the notion of zhongguo based on the traditional divide between Han Chinese and non-Han "barbarians," it then follows how - under the influence of Buddhist cosmology—zhongguo is reimagined to accommodate a more capacious worldview that transcends the ethnic divide, only to return inadvertently to the older traditional worldview. Though inadvertent, this return became the normative Chinese attitude toward outside cultures from the Tang dynasty onward.

It is also worth remarking that the rise of a new Daoist concept of zhongguo based on the ideas of the universe as represented by texts such as the Jiku jing, the Benxiang jing, and the Jieqi jing are all the result of northern Daoists'

22 Zhang Weiran 張偉然 believes that the people of the Tang maintained the ethnic division between Han and non-Han peoples and looked down on non-Han peoples with a sense of cultural superiority. Yet, when it came to politics, they were able to regard them as equals. See Zhang Weiran, "Tangren xinmuzhong de wenhua quyu ji dili yixiang 唐人 心目中的文化區域及地理意象 [Cultural Areas and Geographical Images in the Eyes of Tang People]," in Tangdai diyu jiegou yu yunzuo kongjian 唐代地域結構與運作空 間 [Tang Dynasty Geographic Structure and Their Use of Space], ed. Li Xiaocong 李孝聰 (Shanghai: Shanghai cishu chubanshe, 2003).

23 As Zhang Guangda 張廣達 has pointed out, the Tang, while the most culturally advanced Chinese feudal society, also harbored conservative tendencies. See Zhang Guangda, “Tangdai de zhongwai wenhua huiju he wanqing de zhongxi wenhua chongtu 唐代的 中外文化匯聚和晚清的中西文化沖突 [International Cultural Exchange in the Tang Dynasty and East-West Cultural Conflict in the Late Qing Dynasty]," Zhongguo shehui kexue 中國社會科學 3 (1986): 41 . 
receptiveness to Buddhist theories. The fact that the Benxiang jing increased to twenty-three volumes during the early Tang might speak to the resonance and influence of its ideas. That Daoists finally abandoned this new concept of zhongguo to embrace a traditional worldview is a matter of how the northernoriented Daoist traditions interacted with the environment of the early Tang. This is a topic worth exploring separately.

Ge Zhaoguang once pointed out that the new understandings of geography that Zhang Qian 張騫 brought to China from his western expeditions did not fundamentally change ancient Chinese people's deeply held worldviews; for them, China was still at the center of the world. ${ }^{24}$ At the same time, medieval Buddhists were not the only ones who found the eye-opening discussions of China and the universe in Buddhist scriptures compelling. This revolutionary worldview, which decentered China, the Middle Kingdom, affected medieval Daoism and its followers. When the far-reaching influence of medieval Buddhism and Daoism on Chinese society is considered, rather than concluding that the effect of foreign cosmology on Chinese people is historically insignificant, we should recognize that the unprecedented moment of Chinese receptiveness during the medieval period may shed new light on the relative conservatism and inward-looking attitude that took hold in the dynasties that followed. It is a different perspective on the historical shifts that took place from the period leading up to medieval China until after the Song dynasty.

\section{Works Cited}

Daozang 道藏 [Daoist Canon]. Beijing: Wenwu chubanshe, 1988.

Ge Zhaoguang 葛兆光. Gudai Zhongguo shehui yu wenhua shijiang 古代中國社會與 文化十講 [Ten Lectures on Ancient Chinese Society and Culture]. Beijing: Qinghua daxue chubanshe, 2002.

Liu Yi. "Research into the Catalogue of the Daozang of the Early Tang Dynasty: Based on Nanzhu guan ji and the Daoist Scriptures of Dunhuang." In Scriptures, Schools and Forms of Practice in Daoism: A Berlin Symposium, ed. Poul Andersen and Florian C. Reiter, 191-192. Wiesbaden: Harrassowitz, 2005.

Ōfuchi Ninji 大渊忍爾. Dōkyō to sono kyōten 道教とその經典 [Daoism and Its Canon]. Tokyo: Sōbunsha, 1997.

24 Ge Zhaoguang 葛兆光, Gudai Zhongguo shehui yu wenhua shijiang 古代中國社會與文 化十講 [Ten Lectures on Ancient Chinese Society and Culture] (Beijing: Qinghua daxue chubanshe, 2002), 9 . 
Schipper, Kristofer. "Purity and Strangers: Shifting Boundaries in Medieval Taoism." T'oung Pao 8o (1994): 61-81.

Schipper, Kristofer, and Franciscus Verellen, ed. The Taoist Canon: A Historical Companion to the Daozang. Chicago: University of Chicago Press, 2004.

Tianjin shi yishu bowuguan 天津市藝術博物館. Tianjin shi yishu bowuguancang Dunhuang wenxian 天津市藝術博物館藏敦煌文獻 [Tianjin Art Museum Collection of Dunhuang Documents]. Shanghai: Shanghai guji chubanshe, 1997.

Wang Ming 王明. Baopuzi neipian jiaoshi 抱樸子內篇校釋 [Collation and Explication on the Inner Chapters of the Baopuzi]. Beijing: Zhonghua Book Company, 1985.

Yamada Takashi 山田俊. “Rikuchō kara Tō no dōkyō bunken ni mirareru iteki to gedō 六朝から唐の道教文獻に見られる夷狄と外道 [Barbarians and Heretics as Seen from Daoist Texts from the Six Dynasties to the Tang]." In Sankyō kōshō ronsō 三教 交涉論叢 [Interactions Between the Three Teachings], ed. Mugitani Kunio 麥谷邦夫, 73-97. Kyoto: Kyoto Daigaku Jinbun Kagaku Kenkyūjo, 2005.

Zhang Guangda 張廣達. “Tangdai de zhongwai wenhua huiju he wanqing de zhongxi wenhua chongtu 唐代的中外文化匯聚和晚清的中西文化沖突 [International Cultural Exchange in the Tang Dynasty and East-West Cultural Conflict in the Late Qing Dynasty]." Zhongguo shehui kexue 中國社會科學 3 (1986): 37-51.

Zhang Weiran 張偉然. “Tang ren xinmuzhong de wenhua quyu ji dili yixiang 唐人心目 中的文化區域及地理意象 [Cultural Areas and Geographical Images in the Eyes of Tang People].” In Tangdai diyu jiegou yu yunzuo kongjian 唐代地域結構與運作空間 [Tang Dynasty Geographic Structure and Their Use of Space], ed. Li Xiaocong 李孝聰, 207-412. Shanghai: Shanghai cishu chubanshe, 2003.

Zürcher, Erik. "Buddhist Influence on Early Taoism: A Survey of Scriptural Evidence." T'oung Pao 66 (1980): 84-147. 